\title{
Catalytic Steam Reforming of Bioethanol in Fixed Bed Catalytic Reactor for Hydrogen Production
}

\author{
P. R. TAYADE ${ }^{1 *}$, V. S. SAPKAL ${ }^{2}$, R. S. SAPKAL ${ }^{3}$ and P. V. SAPKAL ${ }^{4}$ \\ ${ }^{1}$ Chemical Engg, Department, Jawaharlal Darda Institute of Engg. \& Technology, \\ Lohara MIDC, Yavatmal-445001, M. S. India \\ ${ }^{2}$ Chemical Technology Department, Sant Gadge Baba Amravati University, \\ Amravati, M.S., India \\ Rashtrasant Tukdoji Maharaj Nagpur University, \\ Nagpur -440001, M.S., India \\ ${ }^{3}$ Department of Chemical Technology, Sant Gadge Baba Amravati University, \\ Amravati-444602, M.S., India \\ ${ }^{4}$ Institute of Chemical Technology, Mumbai, M.S., India \\ praratayade15@gmail.com
}

Received 1 January 2015 / Accepted 21 January 2015

\begin{abstract}
The environmental pollution, global warming and energy crises, all resulted by the extensive use of fossil fuels in automobiles and industry. In this situation of need of sustainable energy, hydrogen as a fuel obtained by steam reforming of bio-derived ethanol (bioethanol) substantially can fulfill the requirement of clean energy for the future. By keeping this view, steam reforming of bioethanol for the production of hydrogen using $10 \% \mathrm{Co}-\mathrm{ZnO}$ catalyst in fixed bed catalytic reactor was studied. For this, a fixed bed tubular SS-316, $15 \mathrm{~mm}$ diameter, $28 \mathrm{~cm}$ in length reactor was developed. The reforming reactions were carried to observe the product distribution under atmospheric pressure condition in the temperature range of $350{ }^{\circ} \mathrm{C}-550{ }^{\circ} \mathrm{C}$ and bio-ethanol to water feed molar ratio of 1: 8 to 1:12. The Co-ZnO catalyst prepared by co-precipitation method has shown very good catalytic activity in the studied range of molar ratio of feed and reforming temperatures.
\end{abstract}

Keywords: Hydrogen, Bioethanol, Reforming, Fixed Bed Reactor, Renewable energy

\section{Introduction}

$\mathrm{CO}_{2}$ is one of the main constituent of ecosystem on the earth; life on the earth developed in accordance of $\mathrm{CO}_{2}$ level that was present in the atmosphere at that time. Now, from the mid of $18^{\text {th }}$ century, we are continuously taking out fossil fuels from the stomach of the earth and adding it into environment in more irregular form (increasing enthalpy of universe). The necessary atmospheric conditions required for life on earth are being continuously disturbed by the extensive use of fossil fuels (adding of $\mathrm{CO}, \mathrm{CO}_{2}, \mathrm{SO}_{\mathrm{x}}, \mathrm{NO}_{\mathrm{x}}, \mathrm{VOC}$ and other pollutants 
in the environment). If this is continuously executed, the life of mankind on the earth will be difficult up to the end of this $21^{\text {st }}$ century. Therefore, it is inevitable to generate alternative new source of energy which must be clean with respect of the environment.

To uphold this priority of clean energy source, hydrogen can substantially fulfill the load of clean energy. Though, till the hydrogen could not stand on the basis of economics if we compare with the cost of fossil fuels, (cost of $\mathrm{H}_{2} / \mathrm{Kg} \approx 2 \mathrm{x}$ cost of fossil fuel $/ \mathrm{kg}$ for large scale production of $\left.\mathrm{H}_{2}\right)^{1}$ due to technological hurdles such as hydrogen storage, transportation and its distribution, continuous research efforts can stand the hydrogen in the global economic era of energy sector. For keeping the view of global cycle of clean and sustainable production of energy, new eco-friendly reservoirs of hydrogen are needed and this can be fulfill by the ethanol or bio-derived ethanol (bioethanol). This research work was done to generate hydrogen using $\mathrm{Co} /$ Zno catalyst by steam reforming of bioethanol which can maintain the $\mathrm{CO}_{2}$ neutral cycle of ecosystem.

Hydrogen is the potential source of clean energy and possesses the highest energy content per unit weight (i.e. $120 \mathrm{~kJ} / \mathrm{g}$ ), as compare to other fuels. Although, most of the used technologies to produce hydrogen are based on natural gas steam reforming, the hydrogen production from bio-liquids such as bioethanol is a promising technology for the future, because it appears as the more attractive alternative due to its renewable characteristics (it is a part of $\mathrm{CO}_{2}$ neutral cycle), high $\mathrm{H}_{2}$ yield and low $\mathrm{CO}_{2}$ emissions ${ }^{2-4}$. In addition to this, most of the Indian region is mainly a farming region and produces the biomass that gives bioethanol by fermentation such as sugarcane molasses, wheat straw, cotton stalk, rice bran etc ${ }^{5}$. Therefore, on the basis of bioethanol as a feedstock for production of $\mathrm{H}_{2}$, more world reforming technologies may attract towards the Indian region in future.

The increase in the yield of $\mathrm{H}_{2}$ by suppressing the side products such as $\mathrm{CO}, \mathrm{CO}_{2}$ and $\mathrm{CH}_{4}$ is the prime requirement of ethanol reforming reaction. Also, if these side products are at minimum level on the product side of this reaction, the purification of $\mathrm{H}_{2}$ will be easy and it will reflect in the improvement of overall process cost of steam reforming of ethanol. Therefore, catalyst is the main crucial part of ethanol steam reforming technology. Lot of researchers has collected the data on number of catalyst ${ }^{6-14}$. Among these catalyst $\mathrm{Co} / \mathrm{ZnO}$, $\mathrm{ZnO}, \mathrm{Rh} / \mathrm{CeO}_{2}$ and $\mathrm{Ni} / \mathrm{Al}_{2} \mathrm{O}_{3}$ are the best suitable catalysts for reforming of ethanol at atmospheric pressure and temperature range of $300-700{ }^{\circ} \mathrm{C}$.

The objective of this research work is to verify the feasibility of $\mathrm{Co} / \mathrm{ZnO}$ supported catalyst in the fixed bed catalytic reactor and to observe the effect of the process parameters such as temperature and bioethanol-to-water feed molar ratio on product distribution of reforming of bioethanol.

\section{Experimental}

Catalyst was prepared by the co-precipitation method from $\mathrm{Zn}\left(\mathrm{NO}_{3}\right)_{2}$ and $\mathrm{Co}\left(\mathrm{NO}_{3}\right)_{2}$ aqueous solutions. In this preparation, catalyst precipitation was accomplished by the addition of a $\mathrm{K}_{2} \mathrm{CO}_{3}$ solution at $40{ }^{\circ} \mathrm{C}$. After aging at $40{ }^{\circ} \mathrm{C}$ for $1.5 \mathrm{~h}$ with vigorously stirring on a heating plate and then resulting solution washed with distilled water. After washing, the samples were dried at $90{ }^{\circ} \mathrm{C}$ overnight. The samples were calcined at $400{ }^{\circ} \mathrm{C}$ under air for $12 \mathrm{~h}$ with a heating rate of $10{ }^{\circ} \mathrm{C} / \mathrm{min}$. After calcinations the catalyst sample was reduced under hydrogen for $12 \mathrm{~h}$ at $400{ }^{\circ} \mathrm{C}$.

\section{Catalyst characterization}

The characterization of $10 \%$ Co-ZnO Catalyst was carried using X-ray Diffraction. In order to identify the component phases present, using the X-ray microdiffractometer Rigaku D-max- 
RAPID, with a cylindrical imaging plate detector, that with $\mathrm{Cu}-\mathrm{K} \alpha$ radiation allows to collect

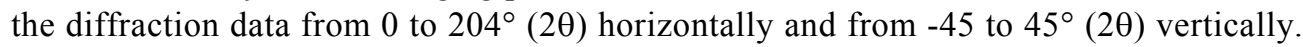
Figure 1 shows the enlarge view of XRD of catalyst samples before reaction. It is clearly observed from the Figure 2 i.e. XRD of catalyst samples after reaction, that intensity of peaks gets reduced after reaction. It is clear indication of reforming of ethanol was happened on the $10 \%$ Co- $\mathrm{ZnO}$ catalyst.

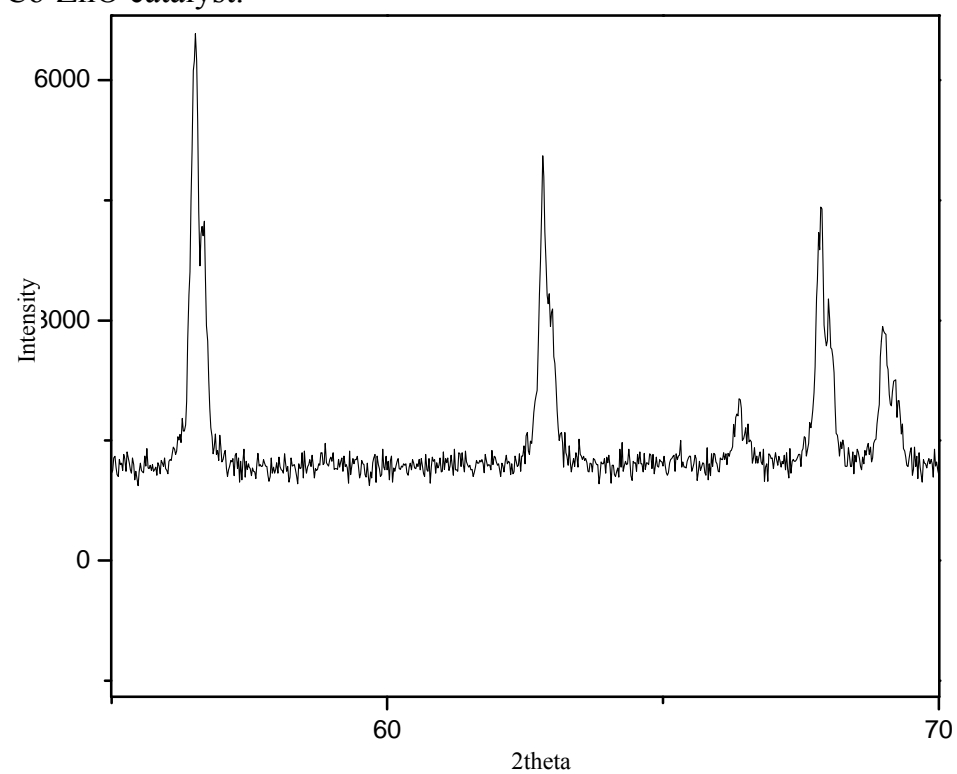

Figure 1. Enlarge view of $\mathrm{XRD}$ for $\mathrm{Co} / \mathrm{ZnO}$ catalyst before reaction

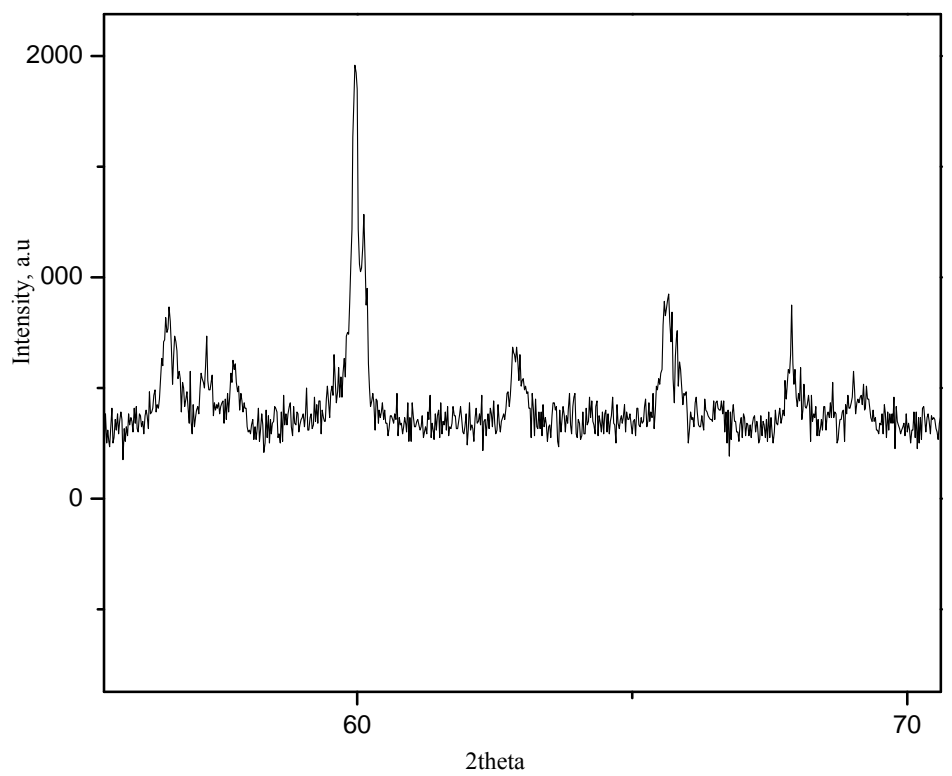

Figure 2. Enlarge view of $\mathrm{XRD}$ for $\mathrm{Co} / \mathrm{ZnO}$ catalyst after reaction 


\section{Experimental Setup}

A proper experimental setup with requisite instrumentation and accessories was designed for the reforming of bioethanol in presence of $10 \%$ of $\mathrm{Co} / \mathrm{ZnO}$. Figure 3 shows the photograph of the actual experimental set-up, whereas Figure 4 shows the schematic flow diagram for the reforming of bioethanol. All the pipe lines from vaporizer to condenser are SS-316 of $1 / 4$ " size; connections are made with ferrule connections and needle valves. The reactor set up consists of following components.

1. Peristaltic feed pump having pumping rate from $1 \mathrm{~mL} / \mathrm{min}-50 \mathrm{~mL} / \mathrm{min}$

2. SS-316 Vaporizer having $8 \mathrm{~cm}$ diameter and $12 \mathrm{~cm}$ length equipped with two $1000 \mathrm{watt}$ ceramic band heaters and a Pt-100 temperature sensor to read the vaporizer temperature

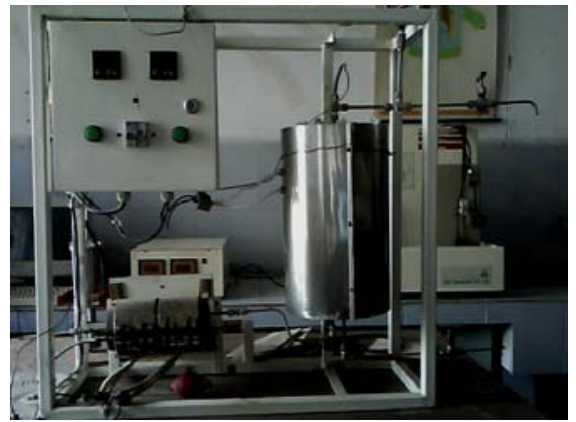

Figure 3. Photo of bio-ethanol steam reforming laboratory plant

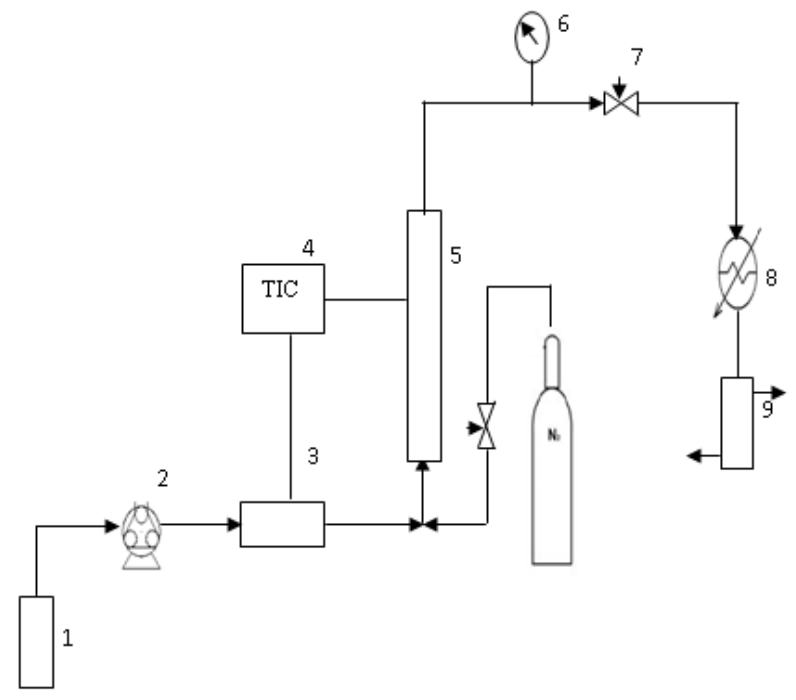

Figure 4. Laboratory flow diagram for bio-ethanol steam reforming.

1. Ethanol and Water feed reservoir, 2. Peristaltic Pump, 3. Water ethanol feed vaporizer, 4. On/off temperature controller, 5. Fixed bed tubular reactor (Reformer), 6. Pressure gauge, 7. Needle valve, 8. Condenser, 9. Gas liquid separator, 10. Nitrogen cylinder

\section{Feed section}

All the gases used in this experimentation with a purity degree of $99.999 \%$. Nitrogen and argon were fed from cylinders, both gases being the gas carrier for bio-ethanol and water 
vapors, therefore by changing temperature and $\mathrm{N}_{2}$ flow rate it is possible to obtain different concentrations in the reaction feed. Also, $\mathrm{N}_{2}$ was used to clean the reactor and to cool the reactor after completion of experimental run.

\section{Reaction section}

A system of three way valves allows feed reactants to the reaction section. In by-pass an independent line is used to send nitrogen to wash the reactor. The reactor shown in Figure 3 was developed by Smart automation Ltd. Pune; it was made of a SS-316 tube of $30 \mathrm{~cm}$ length and internal diameter of $15 \mathrm{~mm}$ placed in a two zone electric oven. The thermocouple is located inside the reactor, in an internal quartz tube of internal diameter of $10 \mathrm{~mm}$ concentric to the reactor. An isothermal zone of $8 \mathrm{~cm}$, with a temperature variation of $\pm 1^{\circ} \mathrm{C}$, was found at $20 \mathrm{~cm}$ from the oven entry (Figure 5). The catalytic bed is located in the isothermal zone.

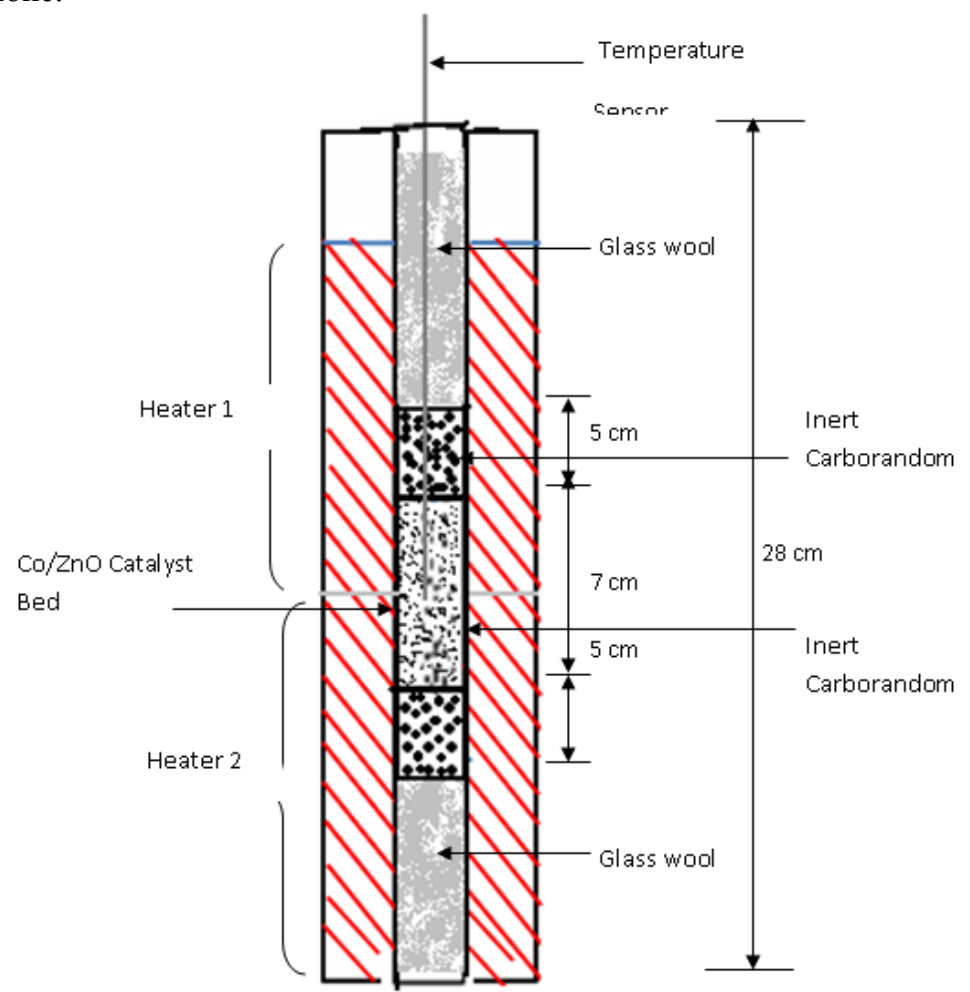

Figure 5. Schematics of Fixed Bed Tubular Reactor (Reformer)

\section{Results and Discussion}

The results reported are based on reactant selectivity to hydrogen and other carboncontaining products. Selectivity to products is defined as follows:

$$
S_{i}(\%)=\frac{n_{i \text { prod }}}{v_{i} n_{\mathrm{C}_{2} \mathrm{H}_{5} \mathrm{OH}} \text { reacted }} \times 100
$$

Where $v_{i}$ is the ratio of stoichiometric reaction coefficients. 


\section{Effect of temperature}

In the reforming of bioethanol the effect of temperature was studied to observe the selectivity behavior of $\mathrm{H}_{2}$ with respect to other reforming bi-products such as $\mathrm{CO}, \mathrm{CO}_{2}$ and methane. The temperature effect reactions were carried at atmospheric pressure on $1 \mathrm{gm}$ of $10 \% \mathrm{Co}-\mathrm{ZnO}$ catalyst with ethanol water molar ratio of $1: 12$ and feed flow rate of $2 \mathrm{~mL} / \mathrm{min}$ for $5 \mathrm{~h}$ by varying the temperature from $350{ }^{\circ} \mathrm{C}$ to $550{ }^{\circ} \mathrm{C}$. It was observed that selectivity of $\mathrm{H}_{2}$ goes on increasing progressively with increase in temperature as shown in Figure 6 and simultaneously $\mathrm{CO}_{2}$ also increase up to $500{ }^{\circ} \mathrm{C}$ and then it becomes steady. The temperature effect on the selectivity of $\mathrm{CO}$ and other gases shows good reverse effect of decreasing selectivity $(15 \%$ to $5 \%)$ with increase in temperature from 350 to $550{ }^{\circ} \mathrm{C}$. Whereas, many of the catalysts have been reported as low temperature reforming catalys $\mathrm{t}^{15,16}$, in that selectivity of $\mathrm{CO}$ and other gases increases with increase in temperature. This, high-reforming temperatures favor the formation the $\mathrm{CO}$, which poisons the anode. As a result, downstream $\mathrm{CO}$ reduction processes such as water gas shift are required. The low temperature ethanol steam reforming faces challenges of formation of undesirable reaction byproducts such as $\mathrm{CH}_{4}$ and carbon. These are thermodynamically favored at low temperatures ${ }^{17,18}$, leading to reduced $\mathrm{H}_{2}$ selectivity and poor catalyst life. Thus, kinetic rather than thermodynamic control of the reaction is required.

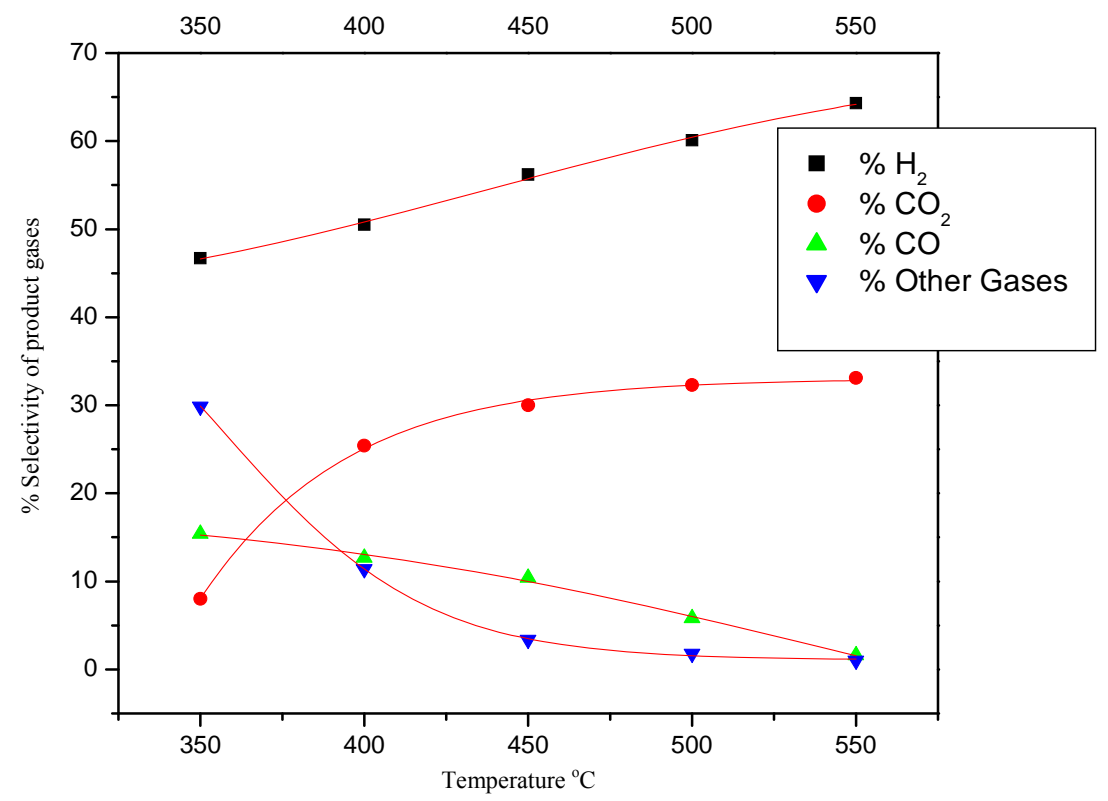

Figure 6. Effect of temperature on selectivity of $\mathrm{H}_{2}, \mathrm{CO}_{2}, \mathrm{CO}$ and other gases formed in the reforming of bioethanol : feed flow rate $2 \mathrm{~mL} / \mathrm{min}$, water: ethanol ratio-12:1, Pressureatmospheric, Weight of catalyst- $1 \mathrm{~g}$, Catalyst particle size- $1 \mathrm{~mm}$.

\section{Effect of water-ethanol mole ratio}

The water-bioethanol molar ratio plays an important role in product selectivity. The effect of water-ethanol ratio was studied for reforming of bioethanol in the molar ratio range of 8:1 to 12:1 at atmospheric pressure and $500{ }^{\circ} \mathrm{C}$ for $1 \mathrm{~g}$ of catalyst and $5 \mathrm{~h}$ times with flow rate of feed solution of $2 \mathrm{~mL} / \mathrm{min}$. The water-ethanol mole ratio shows the similar pattern of effect 
as temperature given shown in Figure 7. It is observed that increase in amount of water in feed solution of reforming reaction leads in the increase of $\mathrm{H}_{2}$ and $\mathrm{CO}_{2}$ formation, $\mathrm{H}_{2}$ reaching from $52 \%$ to near about $60 \%$ by increasing ratio from $1: 8$ to $1: 12$ and $\mathrm{CO}_{2}$ increases from $15 \%$ to $25 \%$. The result of this effect is the decrease in the $\mathrm{CO}$ formation and it goes down from $10 \%$ to $2 \%$. Also, the conversion of ethanol is increases; the main reason of this increase in $\mathrm{H}_{2}$ selectivity and ethanol conversion is low coke formation due to increase in water content in the feed (increase in water ethanol mole ratio). The large excess of water in the feed solution of reforming reaction favors the water gas shift reaction given by the following equation 2

$$
\mathrm{CO}+\mathrm{H}_{2} \mathrm{O} \longrightarrow \mathrm{H}_{2} \mathrm{CO}_{2}
$$

In this reaction $\mathrm{CO}$ gets converted into $\mathrm{H}_{2}$ and $\mathrm{CO}_{2}$, and if more water is available more amount of $\mathrm{CO}$ gets converted into $\mathrm{H}_{2}$ and $\mathrm{CO}_{2}$.

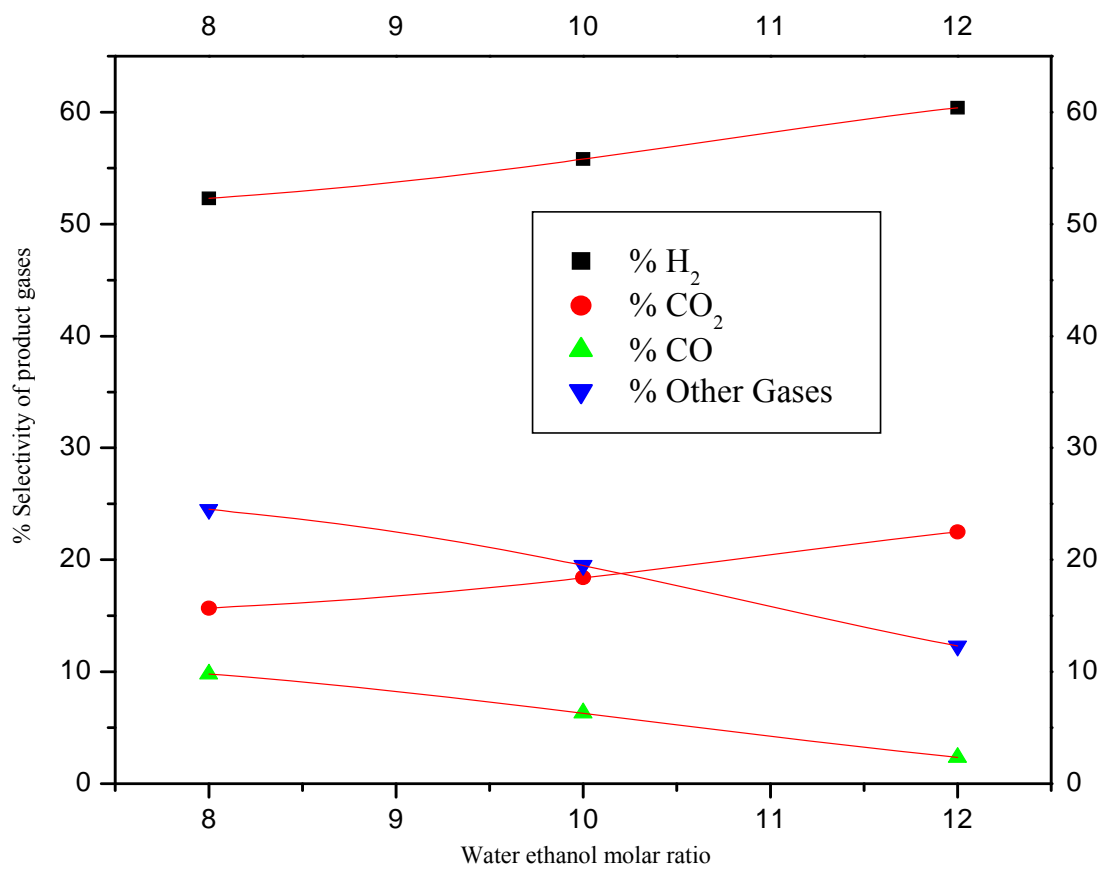

Figure 7. Effect of feed molar ratio on selectivity of $\mathrm{H}_{2}, \mathrm{CO}_{2}, \mathrm{CO}$ and other gases formed in the reforming of bioethanol: Temp $-500{ }^{\circ} \mathrm{C}$, feed flow rate $2 \mathrm{~mL} / \mathrm{min}$, Pressure-atmospheric, Weight of catalyst- $1 \mathrm{~g}$, Catalyst particle size- $1 \mathrm{~mm}$.

\section{Conclusion}

Bio-ethanol is a renewable source of energy, and hydrogen for fuel cell can be efficiently produced from bio-ethanol by the steam reforming reaction. The catalytic performance of $10 \% \mathrm{Co}-\mathrm{ZnO}$ catalyst in the steam reforming of bio-ethanol to produce hydrogen for fuel cell applications was investigated by operating the reactor at different reactor operating conditions. The $10 \% \mathrm{Co}-\mathrm{ZnO}$ catalyst has shown the good effectiveness for the reforming of bioethanol over the given period of experimentation. The product distribution of bio-ethanol reforming reaction over $\mathrm{Co}-\mathrm{ZnO}$ catalyst was found out, $\mathrm{H}_{2}, \mathrm{CO}_{2}$ and $\mathrm{CO}$ as the main products of reaction along with many side products in minute quantity. 


\section{Acknowledgement}

This research was supported by membrane separation group of Chemical Technology Department of SGBAU, Amravati headed by Dr. V. S. Sapkal, Prof \& Head, Chemical Technology Department, SGBAU, Amravati.

\section{References}

1. Antonia H and Marika T, Natural Resources Defense Council Issue Paper, 2005.

2. Comas J, Marino M, Laborde N and Amadeo N, Chem Engg J., 2004, 98(1-2), 61-68; DOI:10.1016/S1385-8947(03)00186-4

3. Athanasio N F and Verykios X E, J Catal., 2004, 225(2), 439-452; DOI:10.1016/j.jcat.2004.04.034

4. Cavallaro S and Freni S, Int J Hydrogen Energy, 1996, 21(6), 465-469; DOI:10.1016/0360-3199(95)00107-7

5. Yun Y, Xia L and Hongwei W, Energy Fuels, 2008, 22(1), 46-60; DOI:10.1021/ef700292p

6. Pilar R P, Homs N, Joaquim S and Fierro L, J Catal., 2004, 222(2), 470-480; DOI:10.1016/j.jcat.2003.12.008

7. Pilar R P, Llorca J, Homs N, Joaquim S and Dalmon J, Appl Catal B: Environ., 2003, 43(4), 355-369; DOI:10.1016/S0926-3373(02)00326-0

8. Benito M, Padilla R, Rodriguez L, Sanz J and Daza L, J Power Sci., 2007, 169(1), 167-176; DOI:10.1016/j.jpowsour.2007.01.047

9. Homs N, Llorca J and Pilar R de la Piscina, Catalysis Today, 2006, 116(3), 361-366; DOI:10.1016/j.cattod.2006.05.081

10. Vargas J C, Libs S, Roger A and Kiennemann A, Catalysis Today, 2005, 107-108: 417-425; DOI:10.1016/j.cattod.2005.07.118

11. Chang Y U, Lee W, Park S and Lee Y, Intl J Hydrogen Energy, 2009, 34((7), 29472954; DOI:10.1016/j.ijhydene.2009.01.039

12. Kugai J, Velu S and Song C, Division Fuel Chemistry, 2003, 48, 754-755.

13. Marino F, Boveri M, Baronetti G and Laborde M, Int J Hydrogen Energy, 2001, 26(7), 665-668; DOI:10.1016/S0360-3199(01)00002-7

14. Carlo R, Cavallarob S, Frusteric F, Frenic S and Guido B, React Kinet Catal Lett., 2007, 90(1), 117-126; DOI:10.1007/s11144-007-5027-2

15. Das N K, Dalai A and Ranganathan R, Canad J Chem Engg, 2007, 85, 92-100; DOI:10.1002/cjce.5450850109

16. Kugai J, Velu S and Song C, Catalysis Letters, 2005, 101(3-4), 255-264; DOI:10.1007/s10562-005-4901-7

17. Fishtik I, Alexander A, Datta R and Geana D, Int J Hydrogen Energy, 2000, 25(1), 31-45; DOI:10.1016/S0360-3199(99)00004-X

18. Tsiakaras P and Demin A, J Power Sources, 2001, 102(1-2), 210-217; DOI:10.1016/S0378-7753(01)00803-5 